\title{
THE NATURE OF THE VIRUS RECEPTORS OF RED CELLS
}

\author{
I. Evidence on the Chemical Nature of the Virds Receptors of Red \\ Cells and of the Existence of a Closely Analogous Substance in \\ NORMAI SERUM
}

By GEORGE K. HIRST, M.D.

(From the Division of Infectious Diseases, The Public Bealth Research Institute of The City of New York)

(Received for publication, December 17, 1947)

The ability of red cells from various species to adsorb and elute the viruses of influenza, mumps, and Newcastle disease is of general interest in the problem of the mechanism of infection by viruses since the red cell-virus system may well involve principles which apply to the virus-host cell relationship. The elution of virus from cells, accompanied by the disappearance of the virus-adsorbing capacity of the cells, indicates that an active destructive process has occurred. It has been suggested (1) that the destruction of receptors is due to an enzyme possessed by the virus, which is active against a substrate possessed by the cell, and no subsequent developments have suggested a more likely alternative. The ultimate goal in proof of this theory is clearly to isolate the cellular substrate and show what type of chemical action the virus may have upon it.

There are several main ways in which the problem may be attacked: (1) attempts to isolate the receptor from the red cell; (2) treatment of the intact cell with reagents which may inactivate the receptor and give some clew to its chemical nature; and (3) searching for analogues of the receptor substance from other biological sources. In the present work only the second and third methods are used.

\section{Methods}

The virus strains used in this work were the PR8 strain of influenza A, the Lee strain of influenza B, and strain L230, which is an influenza A strain isolated in the epidemic of early 1947. The virus suspensions used were all prepared from allantoic fluid and were usually dialyzed against phosphate buffer before use. All of the hemagglutinin and agglutinin inhibition titrations were carried out by the densitometric method of Hirst and Pickels (2) and titers are expressed as the reciprocal of the final dilution of either virus or serum. All titration values have been corrected and given in terms of initial serum or virus concentrations so that they may be directly compared.

\section{EXPERIMENTAL}

The Treatment of Red Cells with Physical and Chemical Agents and Their Effect on the Receptor Substance

Red cells can be exposed to various reagents and tested for their capacity to agglutinate with different quantities of virus but this technique has deficiencies owing to the frequent occurrence of spontaneous red cell agglutination after 
treatment, which renders the test unworkable. Another method of testing the activity of receptors is to measure the amount of virus which treated red cells can absorb from a virus suspension under standard conditions and to compare this with the adsorptive capacity of various concentrations of untreated red cells. By this method the degree of receptor damage is measured in terms of receptor-virus interaction and the purely secondary effect of agglutination is excluded. On comparing the adsorption of treated cells with that of equal and lesser concentrations of normal cells one can estimate in a rough quantitative way the degree of receptor damage.

In the following series of experiments fowl red cells were treated in various ways and, after washing to get rid of the excess of reagent, the cells were tested for their capacity to adsorb virus by mixing them with influenza suspensions at $0^{\circ} \mathrm{C}$. for 30 minutes. The cells were centrifuged out and the supernatant titered for residual unabsorbed hemagglutinin(1). At the same time adsorption was carried out with normal cells, both in the same concentration as the treated cells and in lesser amounts in order to provide a scale of comparison. An example of the change in virus adsorption with various concentrations of cells is given in Table IV. With a relatively high concentration ( 1.5 per cent) adsorption is usually fairly complete and falls off little as the concentration of cells is reduced. With very dilute cell suspensions the adsorption is so small that it cannot be accurately measured in the presence of the large amount of residual virus; but there is a wide range where satisfactory values are obtained.

The most serious drawback to a clear interpretation of the results of this type of experiment is that the reagents used may cause damage to the cell which reduces its adsorption capacity but this does not necessarily mean direct damage to the receptor. Under certain conditions cells or cell debris may adsorb virus in such a manner that it cannot be readily eluted and it is probable that such adsorption is due to substances other than the surface virus receptor. In all tests reported below, complete or nearly complete elution of virus was demonstrated after adsorption on treated cells, though the data are not given in the tables.

\section{Effect of Hemolysis on Virus Receptors}

Red cells were hemolyzed in distilled water and washed thoroughly in saline until free of red color. This treatment results in a considerable change in morphology of the ghosts. Various concentrations of this stromal material and of untreated cells were added to a suspension of PR8 virus and their adsorptive capacity was tested (Table I). The stroma definitely adsorbed (and eluted) virus but had only about one-twentieth of the capacity of untreated cells. Similar results were obtained with stroma prepared by homogenization of cells in saline. 
In another experiment red cells were hemolyzed with saponin (toxic) (1 cc. of a 5 per cent aqueous solution per $4 \mathrm{cc}$. of packed cells) and the ghosts were washed free of visible hemoglobin. In this preparation the morphology of the cells remained intact and their capacity to adsorb virus was undiminished (Table I) and when these ghosts were treated with 5 per cent formalin for 2 days and then washed there was also no effect on their adsorptive capacity. When the cell ghosts were homogenized their adsorptive capacity dropped markedly as in the first experiment detailed. Repeated washing of the stroma does not further reduce the adsorptive capacity.

TABLE I

Adsorption of Virus (PR8) by Red Cells Lysed with Distilled Water and Saponin

\begin{tabular}{|c|c|c|c|c|c|c|c|c|c|c|}
\hline & \multicolumn{4}{|c|}{$\begin{array}{l}\text { Adsorption with normal cells } \\
\text { at various concentrations" }\end{array}$} & \multirow{2}{*}{$\begin{array}{c}\text { Control } \\
\text { no } \\
\text { cells }\end{array}$} & \multicolumn{5}{|c|}{$\begin{array}{l}\text { Adsorption with water-lysed stroma } \\
\text { at various concentrations }\end{array}$} \\
\hline & $\begin{array}{l}3 \text { per } \\
\text { cent }\end{array}$ & $\begin{array}{c}1.5 \\
\text { per } \\
\text { cent }\end{array}$ & $\begin{array}{c}0.75 \\
\text { per } \\
\text { cent }\end{array}$ & $\begin{array}{l}0.37 \\
\text { per } \\
\text { cent }\end{array}$ & & $\begin{array}{c}80 \\
\text { per } \\
\text { cent }\end{array}$ & $\begin{array}{c}40 \\
\text { per } \\
\text { cent }\end{array}$ & $\begin{array}{c}20 \\
\text { per } \\
\text { cent }\end{array}$ & $\begin{array}{c}10 \\
\text { per } \\
\text { cent }\end{array}$ & $\begin{array}{l}5 \text { per } \\
\text { cent }\end{array}$ \\
\hline Titer after adsorption. & 6 & 11 & 20 & 39 & 91 & 4 & 9 & 16 & 32 & 79 \\
\hline \multicolumn{11}{|c|}{ Adsorption with: } \\
\hline & \multicolumn{2}{|c|}{$\begin{array}{l}3 \text { per cent } \\
\text { normal } \\
\text { untrested }\end{array}$} & \multicolumn{2}{|c|}{$\begin{array}{l}\text { Control } \\
\text { no cells }\end{array}$} & \multicolumn{2}{|c|}{$\begin{array}{l}\text { Saponin } \\
\text { ghosts } \\
3 \text { per cent }\end{array}$} & \multicolumn{2}{|c|}{$\begin{array}{l}\text { Saponin } \\
\text { ghosts" in } \\
5 \text { per cent } \\
\text { formalin } \\
3 \text { per cent }\end{array}$} & \multicolumn{2}{|c|}{$\begin{array}{l}\text { Saponin } \\
\text { ghosts* } \\
\text { homogenized } \\
3 \text { per cent }\end{array}$} \\
\hline Titer after adsorption. & \multicolumn{2}{|c|}{74} & \multicolumn{2}{|c|}{294} & \multicolumn{2}{|c|}{74} & \multicolumn{2}{|c|}{60} & \multicolumn{2}{|c|}{208} \\
\hline
\end{tabular}

Red cells or stroma and virus were combined in equal volume at $0^{\circ} \mathrm{C}$. for 30 minutes and after centrifugation the supernatant hemagglutinin titer was tested.

* Concentration expressed in terms of red cells before lysis.

The disappearance of receptor activity when cells are broken up seems to correlate nicely with the findings of Friedewald, Miller, and Whatley (3) who demonstrated the presence of an inhibitor in the supernatant fluid when cells were homogenized, which inhibitor they believe to be the receptor substance. However, if red cells are treated with saponin and the supernatant is dialyzed free of saponin it can be shown to contain a considerable amount of virus inhibitor when tested by Friedewald's technique. Nevertheless, the ghosts from which the inhibitor has been extracted show no decrease in their ability to adsorb virus, indicating either that only a small fraction of the receptors has gone into solution or that some of the extractable inhibitor is of a different character from the virus receptor.

\section{Resistance of Receptors to Heating}

Saline suspensions of 3 per cent red cells were heated at temperatures of $56^{\circ} \mathrm{C}$. and over for 30 minutes and their ability to adsorb virus was tested 
together with that of control cells (Table II). The adsorptive capacity of cells heated at $56^{\circ}$ and $65^{\circ} \mathrm{C}$. did not change detectably, while at higher temperatures specific adsorption (and elution) was found but it was less than 12 per cent of normal and there were considerable hemolysis and breakdown of cells. Since the reduced adsorption after using higher temperatures may have been due to

TABLE II

Adsorption of Virus (PRB) by Red Cells and Water-Lysed Stroma after Heating at Various Temperatures

\begin{tabular}{|c|c|c|c|c|c|c|c|c|c|}
\hline \multicolumn{10}{|c|}{ Whole cells } \\
\hline & \multicolumn{4}{|c|}{$\begin{array}{l}\text { Untreated cells at various } \\
\text { concentrations }\end{array}$} & \multirow{2}{*}{$\begin{array}{l}\text { Control } \\
\text { no cells }\end{array}$} & \multicolumn{4}{|c|}{$\begin{array}{l}3 \text { per cent cells heated for } \\
30 \text { min. at various } \\
\text { temperatures }\end{array}$} \\
\hline “. & $\begin{array}{l}3 \text { per } \\
\text { cent }\end{array}$ & $\begin{array}{c}1.5 \\
\text { per } \\
\text { cent }\end{array}$ & $\begin{array}{l}0.75 \\
\text { per } \\
\text { cent }\end{array}$ & $\begin{array}{l}0.37 \\
\text { per } \\
\text { cent }\end{array}$ & & $56^{\circ}$ & $65^{\circ}$ & $75^{\circ}$ & $85^{\circ}$ \\
\hline Titer after adsorption. & 12 & 20 & 52 & 64 & 182 & 4 & 3 & 97 & 102 \\
\hline \multicolumn{10}{|c|}{ Water-lysed stroma } \\
\hline & \multicolumn{4}{|c|}{$\begin{array}{l}\text { Unheated, at various } \\
\text { concentrations" }\end{array}$} & \multirow{2}{*}{ No stroma } & \multicolumn{4}{|c|}{$\begin{array}{l}60 \text { per cent stroma heated } \\
30 \text { min, at various } \\
\text { temperatures }\end{array}$} \\
\hline & $\begin{array}{c}60 \\
\text { per } \\
\text { cent }\end{array}$ & $\begin{array}{c}30 \\
\text { per } \\
\text { cent }\end{array}$ & $\begin{array}{c}15 \\
\text { per } \\
\text { cent }\end{array}$ & $\begin{array}{l}7.5 \\
\text { per } \\
\text { cent }\end{array}$ & & $56^{\circ}$ & $65^{\circ}$ & $75^{\circ}$ & $85^{\circ}$ \\
\hline Titer after adsorption. & 20 & 39 & 74 & 120 & 182 & 13 & 20 & 39 & 49 \\
\hline
\end{tabular}

Red cells (heated and unheated) were combined in equal volume with PR8 virus (titer 182) and after 30 minutes at $0^{\circ} \mathrm{C}$. the cells were removed and the hemagglutinin titer of the supernatant determined.

* All percentages are in terms of normal cells before lysis.

structural alteration in cells rather than receptor inactivation, a similar experiment was done with cell stroma obtained by hemolysis with water, in which the morphology was already altered, and with this preparation heating at $85^{\circ} \mathrm{C}$. resulted in a loss of only a little over half the activity. It is clear that the receptor substance is quite stable to heat.

\section{Stability of Receptor Substance at Different $p H$ Levels}

PR8 virus was suspended in citrate-phosphate buffer solutions at different $\mathrm{pH}$ levels and after 30 minutes dilutions of the suspensions were made in phosphate buffer ( $\mathrm{pH} 7.1, \mathrm{M}$ 0.11) and the hemagglutinin titered. As shown in Table III there was no adverse effect on the hemagglutinin after suspension in solutions of $\mathrm{pH} 2.4$ to 10.3. Red cells were then suspended in similar buffers covering the same range of $\mathrm{pH}$ and after 30 minutes the cells were washed in 
phosphate buffer at $\mathrm{pH} 7.1$ and were then added in 3 per cent concentration to equal volumes of $P R 8$ virus which had a titer of 270 . All of the cells adsorbed virus well except those which had been exposed to a $\mathrm{pH}$ of 3.14 and 2.60 , the last adsorbing practically no virus. Hemolysis occurred at these lower $\mathrm{pH}$ levels, indicating that the effect may have been due to alteration of the cells and not necessarily the receptor substance.

\section{Effect of Tryptic Digestion on the Receptor Substance}

Tryptic digestion of cells was usually accompanied by some destruction of cell morphology and ordinarily by complete loss of receptor activity. Saponin-

TABLE III

Effect of Exposure at Different pH Levels on the Influenza Virus Hemagghutinin and on Red Cell Receptors

\begin{tabular}{c|c|c|c}
\hline Virus exposed 1 hr. at: & Titer & $\begin{array}{c}\text { Red cells exposed } \\
1 \text { hr. at: }\end{array}$ & $\begin{array}{c}\text { Titer of supernatant } \\
\text { after adsorption }\end{array}$ \\
\hline$p H$ & & $p H$ & \\
2.42 & 256 & $2.60^{*}$ & 208 \\
3.06 & 239 & $3.14^{*}$ & 32 \\
4.12 & 158 & 4.19 & 20 \\
4.78 & 158 & 4.85 & 20 \\
5.40 & 158 & 5.50 & 24 \\
6.11 & 138 & 6.21 & 16 \\
7.10 & 158 & 7.10 & 20 \\
10.33 & 158 & 10.15 & 24 \\
& & Control no cells & 275 \\
\hline
\end{tabular}

* Cells showed some hemolysis after treatment.

lysed cells treated with formalin, however, retained their morphology on digestion with crystalline trypsin but this procedure was accompanied by a marked though not quite complete loss of virus-adsorbing capacity. From this latter result it seemed probable that trypsin had a direct effect on the receptor.

The extraction of cells and stroma with lipid solvents resulted in complete loss of adsorbing capacity but the change in the physical state of the extracted materials was such that no conclusions could be drawn.

\section{The Effect of Oxidizing Agents on the Receptor Substance}

In casting about for reagents which had some degree of specificity against various classes of natural substances the effect of sodium periodate was tested on normal red cells. ${ }^{1}$ This substance even in low concentration was very effective in inactivating the receptor substance without destroying the mor-

1 The author is indebted to Dr. R. D. Hotchkiss of The Rockefeller Institute for Medical Research for this suggestion. 
phology of the cell. In order to try to establish the specificity of this effect various other oxidizing agents were tested (Table IV). Equal volumes of 1.5 per cent red cells were added to these reagents in several strengths and after standing 1 hour the cells were spun out, washed once in $M / 20$ sodium thiosulfate

TABLE IV

Effect of Oxidizing Agents on the Adsorbing Capacily of Red Cells

\begin{tabular}{|c|c|c|c|c|c|c|c|c|c|}
\hline \multirow[b]{3}{*}{ Oxidizing agent } & \multicolumn{6}{|c|}{$\begin{array}{c}\text { Cells treated with oxidizing agent in various } \\
\text { concentrations }\end{array}$} & \multicolumn{3}{|c|}{ Untreated cell controls } \\
\hline & \multicolumn{2}{|c|}{$\mathbf{x} / 10$} & \multicolumn{2}{|c|}{$\mathbf{x} / 100$} & \multicolumn{2}{|c|}{$\mathbf{x} / 1000$} & \multirow[b]{2}{*}{$\begin{array}{l}\text { Concen- } \\
\text { tration } \\
\text { normal } \\
\text { cells }\end{array}$} & \multirow[b]{2}{*}{$\begin{array}{c}\text { Per } \\
\text { cent } \\
\text { of full } \\
\text { concen- } \\
\text { tration }\end{array}$} & \multirow[b]{2}{*}{$\begin{array}{l}\text { Titer } \\
\text { after } \\
\text { adsorp- } \\
\text { tion }\end{array}$} \\
\hline & $\begin{array}{l}\text { Titer } \\
\text { after } \\
\text { adsorp- } \\
\text { tion }\end{array}$ & $\begin{array}{l}\text { Per } \\
\text { cent of } \\
\text { normal } \\
\text { adsorb- } \\
\text { ing } \\
\text { capa- } \\
\text { city }\end{array}$ & $\begin{array}{c}\text { Titer } \\
\text { after } \\
\text { adsorp- } \\
\text { tion }\end{array}$ & $\begin{array}{c}\text { Per } \\
\text { cent of } \\
\text { normal } \\
\text { adsorbing } \\
\text { capacity }\end{array}$ & $\begin{array}{c}\text { Titer } \\
\text { after } \\
\text { adsorp- } \\
\text { tion }\end{array}$ & $\begin{array}{l}\text { Per } \\
\text { cent of } \\
\text { normal } \\
\text { adsorb- } \\
\text { ing } \\
\text { capa- } \\
\text { city }\end{array}$ & & & \\
\hline & & & & & & & per cent & & \\
\hline $\begin{array}{l}\mathrm{K}_{3}(\mathrm{Fe}(\mathrm{CN}))_{8} \ldots \\
\mathrm{KMnO}_{4} \ldots \ldots\end{array}$ & $42 *$ & $\begin{array}{l}90 \\
18\end{array}$ & $14^{*}$ & $\begin{array}{r}100 \\
48\end{array}$ & $\begin{array}{c}5.7 \\
18 *\end{array}$ & $\begin{array}{l}75 \\
45\end{array}$ & $\begin{array}{l}1.50 \\
1.35\end{array}$ & $\begin{array}{r}100 \\
90\end{array}$ & $\begin{array}{l}3.0 \\
3.5\end{array}$ \\
\hline $\mathrm{K}_{2} \mathrm{Cr}_{2} \mathrm{O}_{7} \ldots \ldots$ & $21 *$ & 42 & 3 & 100 & 4 & 79 & 1.20 & 80 & 3.8 \\
\hline$I_{2} \ldots \ldots \ldots \ldots$ & 4 & 79 & 3.7 & 83 & 4 & 79 & 1.05 & 70 & 8.6 \\
\hline $\mathrm{H}_{2} \mathrm{O}_{2} \ldots \ldots \ldots$ & 4 & 79 & 4.3 & 78 & 4.3 & 78 & 0.90 & 60 & 11 \\
\hline $\mathrm{NaIO}_{2} \ldots \ldots \ldots \ldots$ & 3.5 & 90 & 3.2 & 95 & 3.0 & 100 & 0.75 & 50 & 12 \\
\hline $\mathrm{NaIO}_{4}^{*}$ glucose . . . . & 3.5 & 90 & 3.7 & 83 & 3.7 & 83 & 0.60 & 40 & 23 \\
\hline $\mathrm{NaIO}_{4} \ldots \ldots \ldots$ & 97 & 3 & 97 & 3 & 112 & 0 & 0.45 & 30 & 25 \\
\hline & & & & & & & 0.30 & 20 & 37 \\
\hline & & & & & & & 0.15 & 10 & 64 \\
\hline & & & & & & & 0.075 & 5 & 79 \\
\hline & & & & & & & 0.037 & 2.5 & 104 \\
\hline & & & & & & & Control & - & 109 \\
\hline & & & & & & & $\begin{array}{l}\text { no } \\
\text { cells }\end{array}$ & & \\
\hline
\end{tabular}

Equal volumes of cells (1.5 per cent) and oxidizing reagent were combined for 1 hour after which the cells were centrifuged and the supernatant discarded. The cells were washed once with sodium thiosulfate $M / 10$ and twice with saline. The cells were restored to original volume, added to an equal quantity of PR8 virus (titer 109) at $0^{\circ} \mathrm{C}$., kept in suspension for 30 minutes, removed by centrifugation, and the supernatant was titered for hemagglutinins.

* Cells showed marked morphological changes after treatment.

solution and twice in saline. They were tested for their capacity to adsorb influenza virus as compared with normal cells. Except where the reagents caused morphologic changes in the cells their adsorbing capacity was reduced only 25 per cent or less. Considering the very minor changes in adsorption with the control cetls in this range a loss of 25 per cent cannot be considered significant. In marked contrast was the effect of sodium periodate which abolished receptor activity in thousandth molar concentration without any 
change in cellular morphology although there was a change in hemoglobin color and slight hemolysis. Sodium iodate had no effect and neither did periodate to which glucose had been previously added. This would point to a specific oxidizing effect of the periodate radical which is known to affect mainly carbohydrates in biological materials by splitting the carbon-carbon bond where there are adjacent hydroxyl groups.

On the basis of the evidence presented one may say that at least part of the active agent responsible for the adsorption of virus to red cells may be carbohydrate, possibly polysaccharide. ${ }^{2}$ The stability of the receptor to alkali and to heat would be in keeping with this suggestion while the destruction of receptor activity by trypsin indicates that a protein component may be present and necessary for activity.

\section{The Nature of the Inhibitor Substance in Serum}

When the inhibition of agglutination of red cells by influenza virus was first used for the titration of specific antibody (5) it was discovered that the normal sera of rabbits and ferrets, though free from antibody, nevertheless had a fairly high titer of inhibition, so that when normal sera were combined with virus the latter could be prevented from agglutinating red cells even in fairly high dilution of serum. This in vitro inhibition of agglutination is not paralleled by in vivo neutralization except with the influenza A strains of 1947 (6). The inhibitory titer varies from animal to animal and is very high in rabbit and ferret sera but low in horse serum. The inhibitor is extremely stable at high temperatures and resists $100^{\circ} \mathrm{C}$. for 15 minutes. This finding does not accord with that of $\mathrm{McCrea}(7)$ who reported inactivation of rabbit serum inhibitor at $62^{\circ} \mathrm{C}$. Soon after the discovery of the effect of periodates on the receptors of red cells it was found that they had a similar destroying action on the inhibitory substance in normal serum (Table $\mathrm{V}$ ) which suggested that serum inhibitor might be related to the red cell receptor.

One volume of serum (inactivated at $56^{\circ}$ for 30 minutes) was added to one volume of $0.05 \mathrm{M} \mathrm{NaIO}_{4}$ and after 2 hours the remaining periodate was inactivated by the addition of glucose (two volumes of 5 per cent solution). Rabbit sera containing specific influenza antibodies were treated in a similar manner. Sera which were treated with sodium periodate which had been previously inactivated with glucose, and untreated controls were tested together with periodate-treated sera for their inhibitory titer with 4 units of PR8 virus. The inhibitor in normal rabbit serum was reduced by sodium periodate from a titer of 145 to less than 16, while inactivated sodium periodate had no effect.

2 The preliminary observations on the effect of periodate on receptors were made while the author was on the staff of the International Health Division of The Rockefeller Foundation and a brief summary, including the implication of carbohydrate, was published in the annual report of that Division and was made generally available in late 1946 (4). 
The immune rabbit serum was somewhat reduced in titer by sodium periodate. Similar results were obtained with an acute and convalescent pair of sera from human influenza $\mathrm{A}$ infection, with a marked drop in the acute instance and a lesser percentage drop in the inhibitory titer of the convalescent serum.

\section{Action of Oxidizing Agents and Trypsin on Serum Inhibitor}

The same oxidizing agents which were shown to be ineffective in inactivating the virus receptor on the red cell were tested on the inhibitor of normal rabbit serum. Equal volumes of reagent and serum were combined and after 2 hours were dialyzed against a phosphate buffer. $\mathrm{HCl}$ was added to another specimen until the $\mathrm{pH}$ dropped to 2.0 . After 24 hours, dialysis, inhibition tests were

TABLE V

Effect of Sodium Periodate on Agghtination Inhibition with Normal and Immune Sera as Tested with PR8 Virus

\begin{tabular}{|c|c|c|c|c|c|}
\hline Treated with & $\begin{array}{c}\text { Normal } \\
\text { rabbit } \\
\text { serum }\end{array}$ & $\begin{array}{l}\text { Immune } \\
\text { rabbit } \\
\text { serum }\end{array}$ & $\underset{\text { Anfluenza } \mathrm{A}}{\text { human serum }}$ & $\begin{array}{c}\text { Convalescent } \\
\text { influenza } A \\
\text { human serum }\end{array}$ & $\begin{array}{l}\text { Increment of rise } \\
\text { in human serum }\end{array}$ \\
\hline Control............. & 145 & 295 & 111 & 680 & 6.1 times \\
\hline $\mathrm{NaIO}_{2}$ and glucose. . . . . . & 137 & 335 & 111 & 580 & 5.2 times \\
\hline $\mathrm{NaIO}_{4} \ldots \ldots \ldots \ldots \ldots$ & $<16$ & 208 & 16 & 240 & 15 times \\
\hline
\end{tabular}

Reagents (saline, $\mathrm{NaIO}_{4}$ inactivated with glucose, and $\mathrm{NaIO}_{4} \mathrm{~m} / 20$ ) were added to serum in equal volume. After 30 minutes two volumes of glucose were added to the sera receiving periodate. Hemagglutinin inhibition titrations were done with 4 units of PR8 virus.

performed against 4 units of PR8 virus. The results (Table VI) were clear cut and showed no major effect on the inhibitor by any oxidizing agent except sodium periodate, which correlates well with the similar experiment on red cell receptors (Table IV). A pH of 2.0 had no effect on the inhibitory titer, which is consistent with the red cell effect only if one interprets the loss of receptor activity from cells at low $\mathrm{pH}$ as being due to change in cell morphology.

Normal rabbit serum was treated with an equal volume of crystalline trypsin (250 mg. per cent) at $37^{\circ} \mathrm{C}$. for 3 hours with a marked reduction in inhibitory titer as shown in Table VII, an effect which is consistent with the conclusion reached with respect to the effect of trypsin on formalinized red cell ghosts. Lipid extraction did not lower the inhibitory titer of serum.

The analogy of the normal serum inhibitor and the red cell receptor is, on the whole, rather striking in that they both undergo a similar destruction with sodium periodate but not with other oxidizing agents, both are destroyed by trypsin, and both are quite stable to heat and to high $\mathrm{pH}$ levels. A more clinching argument for their similarity would be found if it could be shown that the inhibitor is destroyed by virus. 
Effect of In henza Virus on Normal Serum Inhibitor

If influenza virus can destroy the inhibitor in normal rabbit serum then a titration of normal serum which has been in contact with virus for some time

TABLE VI

Treatment of Normal Rabbit Serum with Oxidizing Agents and Its Effect on Inhibition of Agglutination

\begin{tabular}{|c|c|c|}
\hline \multirow[t]{2}{*}{ Serum treated with: } & \multicolumn{2}{|c|}{$\begin{array}{l}\text { Hemagglutinin inhibition titer after treatment with reagent } \\
\text { in various concentrations }\end{array}$} \\
\hline & $0.1 \mathrm{x}$ & $0.01 \mathrm{M}$ \\
\hline $\mathrm{K}_{3}(\mathrm{Fe}(\mathrm{CN}))_{6} \ldots \ldots \ldots \ldots \ldots \ldots$ & $275 \mathrm{M}$ & $223 \mathrm{M}$ \\
\hline $\mathrm{KMnO}_{4} \ldots \ldots \ldots \ldots \ldots \ldots$ & $147 \mathrm{M}$ & $169 \mathrm{M}$ \\
\hline $\mathrm{K}_{2} \mathrm{Cr}_{2} \mathrm{O}_{7} \ldots \ldots \ldots \ldots \ldots \ldots \ldots$ & $362 \mathrm{M}$ & $275 \mathrm{M}$ \\
\hline $\mathbf{I}_{2} \ldots \ldots \ldots \ldots \ldots \ldots \ldots \ldots \ldots$ & $223 \mathrm{M}$ & $182 \mathrm{M}$ \\
\hline $\mathrm{H}_{2} \mathrm{O}_{2} \ldots \ldots \ldots \ldots \ldots \ldots \ldots$ & $239 \mathrm{M}^{*}$ & $294 \mathrm{M}^{*}$ \\
\hline $\mathrm{NaIO}_{4} \ldots \ldots \ldots \ldots \ldots \ldots \ldots$ & $<8 \mathrm{Mt}$ & $64 M$ \\
\hline $\mathrm{HCl} \ldots \ldots \ldots \ldots \ldots \ldots \ldots \ldots$ & $275 \mathrm{Mg}$ & \\
\hline Control $\ldots \ldots \ldots \ldots \ldots \ldots \ldots$ & $294 \mathbf{M}$ & : \\
\hline
\end{tabular}

Reagents were added in equal volume to undiluted rabbit serum which had previously been inactivated at $56^{\circ} \mathrm{C}$. After 1 hour the mixtures were dialyzed against a phosphate buffer and inhibition tests were carried out in the usual manner against 4 units of PR8 virus. The titrations were not very exact because of volume changes which took place on dialysis, which were not corrected.

* Concentration added was $0.88 \mathrm{M}$.

$\ddagger$ Concentration added was $0.05 \mathrm{M}$.

$\$$ Concentration sufficient to bring to $\mathrm{pH} 2.0, \mathrm{pH}$ was 6.97 after dialysis.

TABLE VII

Inhibition of Agghtination by Serum Treated with Crystalline Trypsin

\begin{tabular}{l|c|c}
\hline & \multicolumn{2}{|c}{ Tested with: } \\
\cline { 2 - 3 } & PR8 Virus & Lee virus \\
\hline Serum control.............................. & $\begin{array}{r}60 \\
<16\end{array}$ & $\begin{array}{r}42 \\
<16\end{array}$ \\
Serum treated with trypsin..... &
\end{tabular}

Equal volumes of serum and trypsin solution (250 mg. per cent) were combined and incubated at $37^{\circ} \mathrm{C}$. for 3 hours.

should give less inhibition on the addition of the test red cells than a similar titration in which the virus had been added to the serum immediately before the addition of cells. When virus was left in contact with serum dilutions for 20 hours or longer very definite decreases in serum inhibition were noted. Very definite decreases in serum inhibition have also been found over short periods of time but involve other techniques which will be described in a later paper. 
In the first experiment (Fig. 1) the L230 strain was used. Normal rabbit serum, inactivated at $56^{\circ} \mathrm{C}$. for 30 minutes, was diluted serially in saline. To one set of serum dilutions virus was added so that the final concentration in each test tube would be 18 units. These tubes stood for 20 hours at room temperature. After 20 hours the same amount of virus was added to a second set of

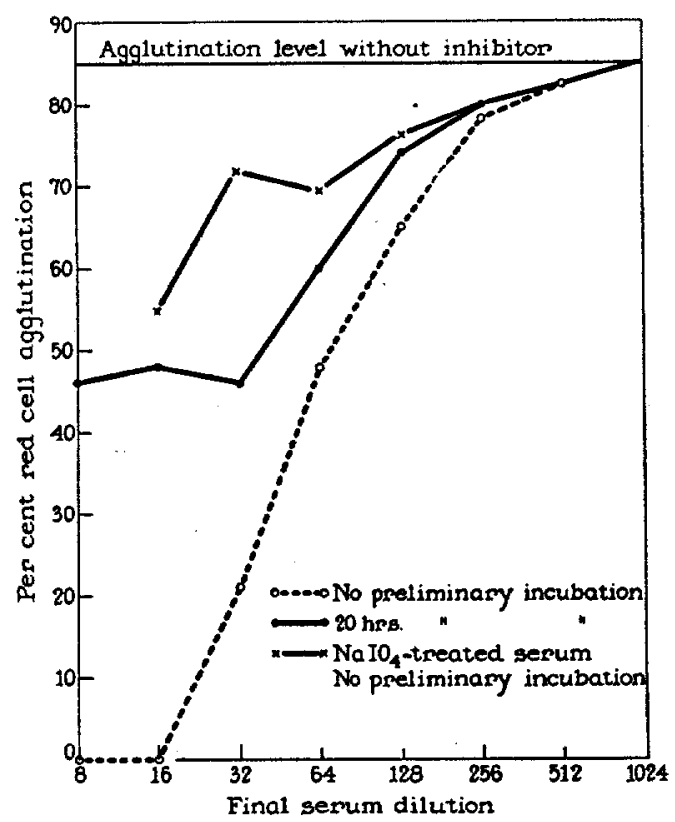

Fig. 1. Agglutination inhibition test with strain L230 virus and normal rabbit serum. In the case of the middle curve (solid line) the virus was added to the serum 20 hours before the red cells. For the lower curve the virus was added 10 minutes before testing. The upper curve represents the results with serum treated with $\mathrm{NaIO}_{4}$ and tested with virus added 10 minutes before testing with red cells. The curves show the percentage of the red cells added which were agglutinated by the virus and sedimented in 75 minutes time. The amount of virus used sufficed to agglutinate 85 per cent of the cells in the absence of any inhibitor.

serum dilutions and after 10 minutes cells were added to the entire test, which was then read in 75 minutes. The percentage of cells agglutinated is plotted for each tube. The amount of virus used was sufficient in the absence of inhibitor to agglutinate 85 per cent of the red cells, but this maximum of agglutination could have been achieved by one-fourth as much virus. The strain used is one which normal sera inhibit to exceptionally high titer and it is even neutralized by normal rabbit sera in in ovo tests (6). When this virus was added to normal rabbit serum just before the addition of the indicator cells there was complete suppression of agglutination in dilutions of serum $1: 8$ and $1: 16$, and detectable inhibition was present at a dilution of 1:512. When virus and 
serum were allowed to stand in contact for 20 hours however, serum-virus mixtures in the lower range of serum dilution showed a marked increase in the agglutination of red cells, from zero to 48 per cent and this increase was significant in dilutions as high as 1:128. Similar results with the Lee strain are shown in Fig. 2. In each case control virus hemagglutinin titrations showed no change in titer over the 20 hour period. For comparison periodate-treated sera are included in each figure, the virus being added in these titrations immediately before the cells.

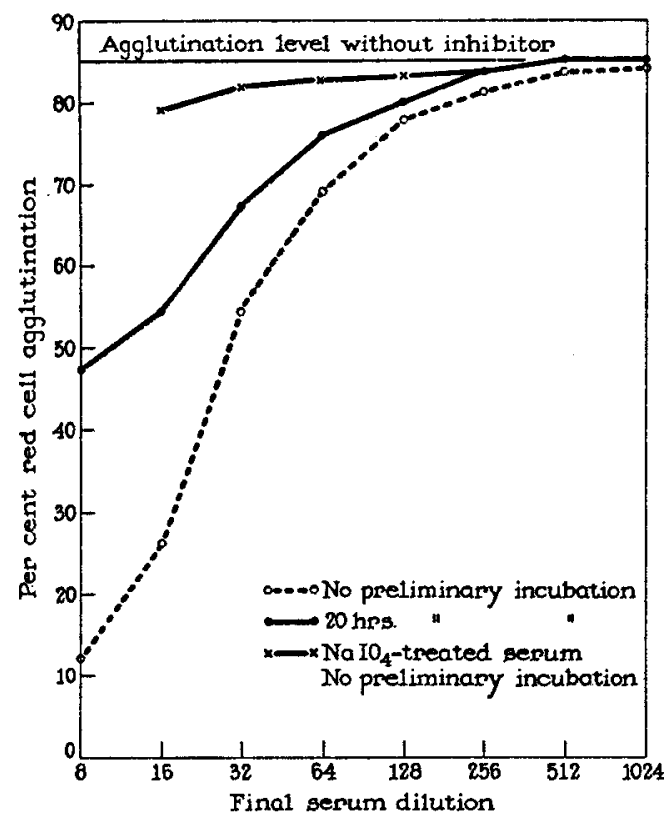

FIG. 2. Agglutination inhibition test with the Lee strain and normal rabbit serum. See legend of Fig. 1.

Contrary to the usual result when an active agent and an inhibitor are allowed to incubate in contact, the virus-inhibitor system showed a decrease in inhibition as virus suspension and inhibitor were allowed to interact. The simplest interpretation of this is that the virus has the ability to destroy the inhibitor in serum. It is possible that the inhibitor is destroyed by an agent present in allantoic fluid not directly connected with the virus. This possibility seems unlikely in view of the analogies of the reaction with that of the red cell-virus system in which the active agent is generally accepted to reside on the virus. Normal allantoic fluid and allantoic fluid from which most of the virus has been removed by centrifugation, do not remove the inhibitory substance from serum while the inhibitor-destroying property is retained by virus purified by centrifugation or by adsorption on, and elution from red cells. 
Burnet, McCrea, and Stone (8) have shown that a cholera vibrio filtrate has the power to remove receptors from red cells in a manner quite analogous to the action of viruses. During the course of this investigation Burnet et al. (9) also reported the inactivation of serum inhibitor with cholera vibrio filtrates and by influenza virus but no details of method for the latter were offered. The main facts concerning the cholera vibrio filtrate have been confirmed in this laboratory.

\section{DISCUSSION}

The discovery that influenza virus after adsorption on red cells or respiratory cells $(1,10)$ elutes readily and completely, suggested strongly that the virus is possessed of an enzyme which is capable of inactivating a receptor substance on red cells. Since that time no contrary hypothesis has been put forward to explain the initial facts and most investigators of the problem have directed their efforts toward tests of this theory. Proof of it very clearly consists in identifying the substrate and the chemical nature of the enzymatic destruction of it by virus.

The present work suggests strongly that the substrate in question is mucopolysaccharide in nature and that both the protein and the polysaccharide components are necessary for its combination with virus. It seems very likely that a close analogue of this receptor substance is present in considerable quantity in normal serum.

The basic facts concerning the action of periodate and the implication of carbohydrate in the receptor substance, published in 1946 (4), suggested the exploration of mucins to Burnet and his collaborators (11). Very recently Burnet (12) has stated, in a preliminary note, that fluid from a pseudomucinous cyst and blood group $O$ substance inhibit influenza virus agglutination markedly, and that the inhibition is reduced by incubating virus and $O$ substance together, probably in a manner analogous to the serum inhibition tests shown here. This is a long step toward the solution of the problem and is completely in keeping with the implications in this paper.

Greene and Woolley (13) have found several naturally occurring polysaccharides (most notably apple pectin) to have a pronounced effect both in inhibition of red cell agglutination by influenza virus and in prevention of infection in chick embryos. Later Ginsberg, Goebel, and Horsfall (14) found that the capsular polysaccharide of type $B$ Friedländer bacillus blocked the agglutination of red cells by mumps virus but not by influenza A or B. Both groups found that red cells could be treated with carbohydrate and then washed and still retain their inagglutinability. The action in these cases seems to be between carbohydrate and red cells, with a specific blocking of receptor points. The demonstration of action between virus and carbohydrate was not convincing and with apple pectin in higher concentrations the red cells were 
actually agglutinated by the carbohydrate. These experiments, though highly interesting, do not suggest that the polysaccharides used were necessarily chemical analogues of the receptor substance. Immersion of red cells in serum containing inhibitor, for example, does not destroy their agglutinability by virus if they are washed before testing, and they do not adsorb inhibitor from the serum.

Both Friedewald, Miller, and Whatley (3) and Bovarnick et al. $(15,16)$ have reported the extraction from cells of virus inhibitors which are destroyed in the presence of virus and which they believe may be the receptor substance in solution. The latter group obtained potent extracts by the use of lipid solvents and their best material contained about 50 per cent polysaccharide. The presence of polysaccharide is in keeping with the work reported above. There is a striking resemblance of the virus receptor substance to the blood group substances in that the form in the cell seems to be water-insoluble while water-soluble forms can be found elsewhere.

The destruction of inhibitor in sera by periodate suggests a practical use for this agent in eliminating this factor from sera which are to be tested for influenza antibody. This aspect of the inhibitor problem will be elaborated in another paper.

\section{SUMMCARY}

The influenza virus receptors of fowl red cells and the influenza virus inhibitor of normal rabbit serum have the following attributes in common: They are stable at high temperatures and in solutions of $\mathrm{pH}$ as high as 10.0. They both resist destruction by a number of oxidizing agents but are readily destroyed by sodium periodate, trypsin, and influenza virus. These facts suggest that the red cell receptor and the normal serum inhibitor are either the same or analogous substances and that they may belong to the mucoprotein class of compounds.

\section{BIBLIOGRAPHY}

1. Hirst, G. K., J. Exp. Med., 1942, 76, 195.

2. Hirst, G. K., and Pickels, E. G., J. Immunol., 1942, 45, 273.

3. Friedewald, W. F., Miller, E. S., and Whatley, L. R., J. Exp. Med., 1947, 86, 65.

4. The Rockefeller Foundation, International Health Division, Annual Report, New York, 1945, 50.

5. Hirst, G. K., J. Exp. Med., 1942, 75, 49.

6. Unpublished observations of the author.

7. McCrea, J. F., Australian J. Exp. Biol. and Med. Sc., 1946, 24, 283.

8. Burnet, F. M., McCrea, J. F., and Stone, J. D., Brit. J. Exp. Path., 1946, 27, 228.

9. Burnet, F. M., McCrea, J. F., and Anderson, S. G., Nature, 1947, 160, 404.

10. Hirst, G. K., J. Exp. Med., 1943, 78, 99. 
11. Burnet, F. M., personal communication.

12. Burnet, F. M., Australian J. Sc., 1947, 10, 21.

13. Green, R. H., and Woolley, D. W., J. Exp. Med., 1947, 86, 55.

14. Ginsberg, H. S., Goebel, W. F., and Horsfall, F. L., Jr., Proc. Soc. Exp. Biol. and Med., 1947, 66, 99.

15. Bovarnick, M., and deBurgh, P. M., Science 1947, 105, 550.

16. deBurgh, P. M., Yu, P.C., Howe, C., and Bovarnick, M. J., Exp. Med., 1948, $87,1$. 